\title{
Developing Vietnamese Individual Economy in the \\ Context of International Economic Integration: Research at Vinh Phuc Province
}

\author{
Nguyen Thi Thu Hương (Correspondence author) \\ Academy of Finance, Hanoi, Vietnam \\ Do Thi Nang \\ Academy of Finance, Hanoi, Vietnam
}

Ho Thi Hoa

Academy of Finance, Hanoi, Vietnam

Tran Thi Hien

Academy of Finance, Hanoi, Vietnam

Nguyen Quang Sang

Academy of Finance, Hanoi, Vietnam

Le Hoang Anh

Academy of Finance, Hanoi, Vietnam

$\begin{array}{ll}\text { Received: February 27, } 2021 & \text { Accepted: March 5, } 2021 \quad \text { Published: March 11, } 2021 \\ \text { doi:10.5296/jad.v7i1.18352 } & \text { URL: https://doi.org/10.5296/jad.v7i1.18352 }\end{array}$ 
Abstract

Economic restructuring has been one of the urgent requirements for the Vietnamese economy, especially in the context of the expanding the economy in the industrial revolution 4.0. The growth effects are intensifying and the growth rate seems to slow down. The individual economy is considered to be one of the important drivers for economic growth in Vietnam in the upcoming years. As the region with the largest proportion in the economy, about $40 \%$ of GDP (Thanh Binh, 2018), the achievement of economic restructuring goals in the direction of industry restructuring, agriculture developing of worms processing, refined processing of agriculture, forestry, fisheries, manufacturing; increasing the internal productivity of the industry, increasing the technology content and the proportion of domestic value in the product, etc. This article focuses on analyzing the situation of individual economy development in Vinh Phuc province, Vietnam, pointing out the achievements, limitations, causes and some recommendations to promote individual economy development in Vinh Phuc province, Vietnam in the context of world economic integration.

Keywords: Development, individual economy, Vietnam

\section{Introduction}

Vinh Phuc is a province in the key economic region of North Vietnam, is the gateway to the capital, near Noi Bai International Airport, is the bridge between the Northwest provinces with Hanoi and the Red River Delta. Therefore, the province plays a very important role in the economic development strategy of the region and Vietnam. The individual economy sector of Vinh Phuc has developed quite rapidly, as of 2018, the whole province has a total of 73,362 enterprises (Vinh Phuc Statistical Yearbook, 2019). Thanks to an improving investment and business environment, a flourishing consumer market, most businesses produce and trade effectively. Many businesses have adjusted to increase capital, expand production scale, invest in upgrading production lines, renovate designs, improve product quality, expand consumption markets; not only to contribute to solving jobs for laborers and increasing state budget revenues but also creating a new breakthrough in industrial development, attracting investment, creating a solid foundation to soon turn Vinh Phuc into a modern industrial province in 2020.

However, the individual economy sector in Vinh Phuc province still faces many difficulties: The investment capital is small, mainly loans, the business structure is not reasonable. Most of the production technology is at an average level, the machinery system and equipment are lacking and outdated. Product models are not diversified and suitable with consumer tastes. Enterprises have not focused on building brand names, have not reached out and ensured their ability to stand firmly in the market. The relationship of cooperation, joint venture in production and business between enterprises remains weak. Business management team still has limited knowledge, experience and management capacity. Most of the labors in the enterprises are low-skilled, few skilled technicians.

In this situation, let the private sector continue to promote its traditional role as well as consolidate and enhance a new role for the development of Vinh Phuc province in the context 
of world economic integration. absolutely necessary. Stemming from the above practice, the authors want to share their views and propose a number of recommendations with scientific and practical basis on this issue.

\section{Literature Review}

Dac (2017) thinks that the individual economy is the most important subject in the modern market economy. While the size of the private sector may differ in diverse market economy models, it is certain that without the private sector there would be no market economy. in its own right. Despite its imperfections, the market economy still proves to be the best-today-considered mechanism for mobilizing, distributing resources, promoting innovation and development. It is the activities of the private sector that help operate that mechanism. A developed private sector is unlikely to bring about a perfect market economy. The private sector itself does not help to overcome the shortcomings and "failures" of the market. However, if the individual economy is not developed, it will not be possible to bring into full play the strength of the market economy and fully exploit the great development resources of the society. The private sector is part of a country's economic system run by individuals and companies, not the government. Most private sector organizations are run for a profit. The private sector is larger in free enterprise economies, such as the United States, in which the government imposes relatively few restrictions on business. In countries with more government control, such as China, the public sector accounts for a larger share of the economy (Ivy, 2013). The UNESCO (2016) Science Report observes that many low-income countries have used their strong economic growth over the past decade during the commodities boom to develop infrastructure, such as roads, railways, ports, hospitals, schools and universities. Countries are also conscious of the need to diversify their economies, in order to create jobs and reduce their vulnerability to fluctuating global market prices for raw commodities.

Son (2017) commented: The role and position of the individual economy in the socialist-oriented market economy and international integration are increasingly being perceived and appreciated. The individual economy has contributed more and more to the mobilization of social resources for investment in production and business development, economic growth, economic restructuring, increasing state budget revenue, and creating jobs. , improving people's life, ensuring social security, solving social problems. The private sector is a key stakeholder in both urban and economic development, being a major contributor to national income and the principal job creator and employer. The private sector provides around $90 \%$ of employment in the developing world (including formal and informal jobs), delivers critical goods and services and Vo to tax revenues and the efficient flow of capital. Further, it will undertake the majority of future development in urban areas (Venables, 2015).

Phuc (2019) affirms that the business relationship between the state economy and the individual economy is essentially a form of state capitalism. It is the mechanism through which the State can direct the development of the individual economy sector in order to achieve socio-economic goals that the State has set out as the rich, the strong, the owner, fair, 


\section{MInstitute Macrothink $_{\text {Int }}$}

civilized. In the process of campaigning under the laws of the market economy, the individual economy sector cannot avoid restrictions such as unfair competition, overproduction, violation of laws and market discipline, creating the risk of economic - financial crisis, environmental damage, social inequality, etc. (Vu Dinh Anh, 2019). Lorenzo Pavone (2015) Challenges exist, however, to maximising the private sector's role in economic development. Both the conditions businesses face and how they act have consequences. On one hand, businesses often work in difficult environments, where corruption is rampant, the rule of law is not enforced, and infrastructure and services are poor.

In order for a business strategy to be highly feasible, author Pham Thi Luong Dieu (2018) said that: private enterprises need to carefully study the country's socio-economic goals, industry and career development strategies. ; at the same time, seize their ability to formulate strategies for the future. Each enterprise needs to develop its own strategy, in accordance with the ability of capital, human capacity, development goals, business lines...Enterprises can choose their own strategies, such as: product strategy; price strategy; product distribution strategy; Growth strategy; financial strategy; HR organization strategy; corporate external strategy... supporting the individual economy to innovate, modernize technology and develop human resources, and improve labor productivity. Implementing this solution is to encourage and create all opportunities for private enterprises to access and apply advanced technology in production and business. Encourage scientific institutions, managers and scientists to associate with enterprises in training human resources for enterprises and transferring new and advanced technologies to enterprises (Xuan Hai, 2017).

\section{Method}

The authors mainly use descriptive statistical methods, sociological survey methods to analyze reality, results and limit the individual economic development situation in Vinh Phuc province, Vietnam. Data are collected and synthesized from the Statistical Yearbook of Vinh Phuc Province in 2019, Vietnam; Small and medium enterprise support and development project in Vinh Phuc province in the period 2020-2025, first draft.

\section{Individual Economy Development in Vinh Phuc Province, Vietnam}

\subsection{Overview of Natural and Socio-Economic Conditions for Individual Economy Development in Vinh Phuc Province}

\subsubsection{Natural Condition}

Vinh Phuc province has a natural area of 1,235.15 km2 (according to the 2017 statistical yearbook), the North borders Tuyen Quang and Thai Nguyen provinces, the West borders Phu Tho province, the South borders Hanoi, the East borders two districts. Soc Son and Dong Anh - Hanoi, with a population of over one million people (according to the 2017 statistical yearbook), there are 7 ethnic groups living in the province including: Kinh, San Diu, Nung, Dao, and Cao. Lan, Muong. The province has 9 administrative units: 2 cities (Vinh Yen, Phuc Yen) and 7 districts (Tam Duong, Tam Dao, Yen Lac, Vinh Tuong, Lap Thach, Song Lo, Binh Xuyen); 137 communes, wards and towns. This is a condition that creates a comparative advantage in the development of private enterprises commensurate with the available 
potentials and promotes a sustainable socio-economic development.

4.1.2 The Socio-Economic Situation of Vinh Phuc Province Affects the Individual Economic Development

After 20 years of re-establishment, under the leadership of the Provincial Party Committee, People's Council, and People's Committee, Vinh Phuc has achieved many important and proud achievements. From an agricultural province to a province with great industrial production value, it is the leading automobile and motorcycle production center of the northern key economic region and the whole country. Technical infrastructure system has been invested and upgraded in a modern direction. The fields of education, health, culture and information have many changes; National defense security has been strengthened, social order and safety have been maintained.

The average economic growth of Vinh Phuc in the 2016-2020 period is estimated at $7.1 \%$ per year, $0.74 \%$ higher than that in the $2011-2015$ period. The scale of the economy in 2020 is estimated at over 122. 68 trillion VND, 1.56 times higher than 2015. The average gross product (GRDP) per capita in 2020 is estimated at 104. 68 million VND per person, increasing 32.5 million dong compared to 2015. In 2019, the province's GRDP size ranks 6th and the GRDP per capita value ranks 5 th in the Northern key economic region. The economic structure in 2020 is construction industry $61.59 \%$; services $30.26 \%$; agriculture, forestry and fisheries $8.15 \%$ (compared to 2015, industry and services increase 2.39\%; forestry and fisheries decrease 2.39\%) (Le Thi Dieu, 2020).

In 5 years, it attracted 2.86 billion USD of investment capital from FDI projects and 56.27 trillion VND of investment capital from DDI projects. Attracting 5 ODA projects reaching 258 million USD, investing in infrastructure, water treatment and management in the area. When the province was re-established (in 1997), the province had only 8 FDI projects, now there are 384 FDI projects from 18 countries and territories, 755 DDI projects. In 2019, Vinh Phuc ranked 19th out of 63 provinces and cities; ranked 6th among the Red River Delta provinces in attracting foreign investment (Le Thi Article, 2020).

However, besides the results achieved, the socio-economic development of Vinh Phuc still has certain limitations. Economic growth shows signs of slowing down; economic growth quality is not sustainable; resource attraction and ineffective management and use of resources; State management quality of land and minerals has not met the requirements; human resources are lacking in both quantity and quality, etc. These shortcomings require the authorities at all levels in the province to find out effective solutions soon.

\subsection{Situation of Individual Economic Development in Vinh Phuc Province, Vietnam}

4.2.1 Develop the individual economy in Vinh Phuc Province 
Table 1. Number of private sector in Vinh Phuc province from 2010 to 2018

Unit: Enterprise

\begin{tabular}{llllll}
\hline Year & $\mathbf{2 0 1 0}$ & $\mathbf{2 0 1 5}$ & $\mathbf{2 0 1 6}$ & $\mathbf{2 0 1 7}$ & $\mathbf{2 0 1 8}$ \\
\hline Enterprise & 1,472 & 2,741 & 3,544 & 4,429 & 4,889 \\
Private enterprise & 242 & 237 & 275 & 243 & 210 \\
Limited liability company & 998 & 1,938 & 2,463 & 3,195 & 3,574 \\
State-owned joint stock companies & 3 & 3 & 3 & 2 & 9 \\
Joint stock companies do not have state capital & 229 & 563 & 803 & 989 & 1,096 \\
\hline
\end{tabular}

Source: Vinh Phuc Statistical Yearbook 2019.

Table 1 shows:

- The number of private enterprises in Vinh Phuc tends to decrease in quantity: decrease in 2015 compared to 2010 is $2.07 \%$; in 2016 increased $16.03 \%$ as compared to 2015 ; in 2017 decreased by $11.64 \%$ compared to 2016 ; decrease in 2018 compared to 2017 is $13.58 \%$.

- The number of limited liability companies in Vinh Phuc province tends to increase in quantity: in 2015, it is $94.19 \%$ higher than 2010 ; in 2016 increased by $27.09 \%$ compared to 2015 ; in 2017 , an increase of $29.72 \%$ compared to 2016 ; in 2018 , it was $11.86 \%$ higher than 2017.

- The number of joint stock companies with state capital in Vinh Phuc did not change in the period 2010-2016; decrease in 2017 compared to 2016 is $33.33 \%$; in 2018 , it is $450 \%$ higher than 2017.

- The number of joint stock companies without state capital Vinh Phuc tends to increase strongly in quantity: in 2015, it is $245.85 \%$ increase compared to 2010 ; in 2016 , it is $142.62 \%$ higher than 2015; in 2017 increased $123.16 \%$ compared to 2016; in 2018, it is $110.82 \%$ higher than 2017.

Thus, the individual economy of Vinh Phuc in the period 2010-2018 tends to increase mainly due to the increase in the number of limited liability companies and joint stock companies without state capital. Along with the growth in quantity, the individual economy of Vinh Phuc also has a qualitative development. From operating in a few sub-sectors, mainly such as small mechanics, consumer ceramics, preliminary processing of agricultural and food products, industrial enterprises have expanded to many other fields, providing many types of products to the market, but the company's products are mainly consumed in the province. Enterprises 
in the individual economy sector registered to operate in important industries to improve their competitiveness are still very small, accounting for only a small proportion such as: information technology, software, electronics and informatics. science and technology, etc. The individual economy in the province operates mainly in industries with low added value and increased labor, investing in industries based on knowledge and technology. or using a lot of capital is limited.

\subsubsection{Resources for Individual Economic Development in Vinh Phuc Province}

* Capital of the private sector in Vinh Phuc

Table 2. Average annual production and business capital of the private sector in Vinh Phuc by type of enterprises

Unit: million VND

\begin{tabular}{|c|c|c|c|c|c|}
\hline Year & 2010 & 2015 & 2016 & 2017 & 2018 \\
\hline Enterprise & $18,206,128$ & $45,674,446$ & $61,934,54 c$ & $86,145,835$ & $110,305,469$ \\
\hline Private enterprise & $1,539,256$ & $1,827,049$ & $1,710,991$ & $1,675,111$ & $1,368,819$ \\
\hline Limited liability company & $8,471,587$ & $27,638,997$ & $32,363,678$ & $45,810,083$ & $38,494,502$ \\
\hline $\begin{array}{l}\text { State-owned joint } \quad \text { stock } \\
\text { companies }\end{array}$ & 105,673 & 134,561 & 660,346 & 85,556 & 325,718 \\
\hline $\begin{array}{l}\text { Joint stock companies do not } \\
\text { have state capital }\end{array}$ & $8,089,612$ & $16,073,839$ & $27,199,53$ & $38,575,085$ & $50,116,430$ \\
\hline
\end{tabular}

Source: Vinh Phuc Statistical Yearbook 2019.

The average annual production and business capital of the private sector of Vinh Phuc increased sharply in the period 2010-2018: in 2010 was 18,206,128 million VND to $110,305,469$ million VND in 2018. Of which, the largest increase was capital. Export of limited liability companies: in 2010 was 8,471,587 million VND, in 2018 up to 58,494,502 million VND, up nearly $690.48 \%$ compared to 2010 . Next is joint stock company without state capital : capital production in 2010 was 8,089,612 million VND, increased to $50,116,430$ million VND in 2018, increased 619. 52\% compared to 2010 (Table 2).

In 2010, the average annual production and business capital of the private sector of Vinh Phuc accounted for $40.64 \%$ of the average annual production and business capital of Vinh Phuc enterprise. In 2015, it decreased to $35.70 \%$ and in 2016 it was $38.65 \%$. In 2017 it increased to $41.65 \%$ and in 2018 it was $43.23 \%$ (Table 2). 
Table 3. Vinh Phuc individual economy in operation as in December 31, 2018 by capital scale Unit: million VND

\begin{tabular}{|c|c|c|c|c|c|}
\hline & \multirow[b]{2}{*}{ Total } & \multicolumn{4}{|c|}{ By size of capital } \\
\hline & & $\begin{array}{l}\text { Less than } \\
0.5 \text { billion } \\
\text { VND }\end{array}$ & $\begin{array}{l}\text { From } 0.5 \\
\text { billion to } 1 \\
\text { billion VND }\end{array}$ & $\begin{array}{l}\text { From } 1 \text { billion } \\
\text { to } 500 \text { billion } \\
\text { VND }\end{array}$ & $\begin{array}{l}\text { Over } 500 \\
\text { billion } \\
\text { VND }\end{array}$ \\
\hline Enterprise & 4,889 & 298 & 332 & 4,224 & 35 \\
\hline Private enterprise & 210 & 36 & 20 & 154 & - \\
\hline $\begin{array}{l}\text { Limited liability } \\
\text { company }\end{array}$ & 3,574 & 216 & 268 & 3,075 & 15 \\
\hline $\begin{array}{l}\text { State-owned joint } \\
\text { stock companies }\end{array}$ & 9 & - & - & 9 & - \\
\hline $\begin{array}{l}\text { Joint stock companies } \\
\text { do not have state } \\
\text { capital }\end{array}$ & 1,096 & 46 & 44 & 986 & 20 \\
\hline
\end{tabular}

Source: Vinh Phuc Statistical Yearbook 2019.

Table 3 shows that the private sector of Vinh Phuc is mainly micro-enterprises, small and medium-sized enterprises account for $99.28 \%$, leading to limited access to credit sources and technological innovation., participating in national, regional and global supply chains.

* Labor resources of the private sector of Vinh Phuc

Table 4 shows the highest job creation for limited liability company (in 2018 it was 43,331 employees); followed by Joint Stock Company (in 2018, it was 27,948 employees); The number of employees working in private enterprises tends to decrease gradually (in 2010 it was 3,188 employees in 2018, it was 1,565 employees, down $49 \%$ ).

The individual economy creates many jobs for workers, especially rural workers, and workers begin to participate in the job market, mainly in rural areas, and switch to work in non-agricultural sectors. industry, contributing to promoting the transformation of labor structure and division of labor between branches and localities in the province. Facilitate improving the rate of trained labor in the province, through training, improving workers' skills and developing human resources for a large portion of agricultural workers and starting number of employees Participating in the labor market when working in enterprises are 


\section{Macrothink}

trained to gradually adapt to the labor order, manners and discipline in the enterprise.

Table 4. Total number of employees in the private sector of Vinh Phuc province as of December 31 annually

Unit: person

\begin{tabular}{llllll}
\hline Year & $\mathbf{2 0 1 0}$ & $\mathbf{2 0 1 5}$ & $\mathbf{2 0 1 6}$ & $\mathbf{2 0 1 7}$ & $\mathbf{2 0 1 8}$ \\
\hline Enterprise & 38,722 & 53,348 & 66,150 & 71,665 & 73,362 \\
Private enterprise & 3,188 & 2,270 & 2,939 & 2,150 & 1,565 \\
Limited liability company & 20,910 & 28,794 & 37,805 & 41,537 & 43,331 \\
State-owned joint stock companies & 868 & 459 & 490 & 307 & 518 \\
Joint stock companies do not have state capital & 13,756 & 21,825 & 24,916 & 27,671 & 27,948
\end{tabular}

Source: Vinh Phuc Statistical Yearbook 2019.

In the period 2013-2018, the labor training index of Vinh Phuc increased from 5.94 (2013) to 7.15 (2018). According to enterprises' assessment in 2018, the quality of vocational education (14\% higher than the national average) and general education (5\% higher than the national average) both increased compared to the previous year; Employees in the province meeting the needs of businesses to reach $94 \%$ (higher than the national average of $4 \%$ ); Rate of trained workers / number of untrained workers is $5 \%$ higher than the national average; The rate of trained workers / total workforce is $5 \%$ higher than the national average. Thus, the quality of the labor force in the province has improved and contributed to the formation of a human resource that ensures quality and quality, meeting the needs of the business (SME Support and Development Scheme above in Vinh Phuc province in the period of 2020-2025, the first draft).

* Fixed asset value of the private sector of Vinh Phuc 


\section{Macrothink}

Journal of Asian Development

ISSN 2377-9594 2021, Vol. 7, No. 1

Table 5. Fixed asset value of the private sector in Vinh Phuc from 2010 to 2018

Unit: million VND

\begin{tabular}{llllll}
\hline Year & $\mathbf{2 0 1 0}$ & $\mathbf{2 0 1 5}$ & $\mathbf{2 0 1 6}$ & $\mathbf{2 0 1 7}$ & $\mathbf{2 0 1 8}$ \\
\hline Enterprise & $7,933,272$ & $13,346,795$ & $20,196,977$ & $28,356,724$ & $37,315,757$ \\
Private enterprise & 540,523 & 418,892 & 386,958 & 404,828 & 255,456 \\
$\begin{array}{l}\text { Limited liability } \\
\text { company }\end{array}$ & $2,975,762$ & $7,604,380$ & $9,181,078$ & $13,010,585$ & $18,420,767$ \\
$\begin{array}{l}\text { State-owned joint stock } \\
\text { companies }\end{array}$ & 54,762 & 65,209 & 556,989 & 31,271 & 55,619 \\
$\begin{array}{l}\text { Joint stock companies do } \\
\text { not have state capital }\end{array}$ & $4,362,225$ & $5,258,314$ & $10,071,952$ & $14,910,040$ & $18,583,915$ \\
\hline
\end{tabular}

Source: Vinh Phuc Statistical Yearbook 2019.

The value of fixed assets of the private sector of Vinh Phuc increased sharply in the period 2010-2018: in 2010 was 7,933,272 million VND; In 2018, it was 37,315,757 million VND, an increase of $470.37 \%$ compared to 2010 . In which the strongest increase was the fixed asset value of a limited liability company in 2010 which was 2,975,762 million VND in 2018 was 18,420 . VND 767 million, an increase of $619 \%$ compared to 2010 . Followed by the value of fixed assets of a joint stock company without state capital in 2010 was VND 4,362,225 million in 2018 was VND 18,583,915 million, up 426\% from with 2010. Meanwhile, the fixed asset value of private enterprises decreased in 2010 to 540,523 million VND, in 2018 it was 255,456 million VND, equal to $47.26 \%$ compared to 2010 (Table 5). 


\section{Macrothink}

Journal of Asian Development

ISSN 2377-9594 2021, Vol. 7, No. 1

Table 6. Average fixed assets equipment per employee per employee in Vinh Phuc province from 2010 to 2018

Unit: million VND

\begin{tabular}{lccccc}
\hline Equip fixed assets on average 1 employee & $\mathbf{2 0 1 0}$ & $\mathbf{2 0 1 5}$ & $\mathbf{2 0 1 6}$ & $\mathbf{2 0 1 7}$ & $\mathbf{2 0 1 8}$ \\
\hline TOTAL & 256.3 & 341.5 & 360.9 & 397.5 & 275.9 \\
State enterprise & 405 & 692.2 & 849.3 & 987.5 & $1,209.70$ \\
Personal economic & 193.9 & 250.2 & 305.3 & 395.7 & 293.4 \\
Foreign-invested enterprises & 316.5 & 392.9 & 387.1 & 385.2 & 505.2 \\
\hline
\end{tabular}

Source: Vinh Phuc Statistical Yearbook 2019.

Equip fixed assets per employee of state-owned enterprises increased the most in the 2010-2018 period, namely: 405 million VND in 2010, 1,209.70 million VND in 2018, up $298.69 \%$ compared to that of As compared with 2010. Equipping with fixed assets per employee of a foreign-invested enterprise in 2010 was 316.5 million VND, in 2018 it was 505.2 million VND, increasing 159.62\% compared to 2010. Equipping fixed assets per employee of non-state enterprises on average in 2010 was 193.9 million VND, in 2018 it was 293.4 million VND, increasing 183.81\% compared to 2010. That shows that Vinh Phuc private sector has focused on promoting investment in fixed assets to improve the competitiveness of products in the market. But due to low equity capital and small firm size, the private sector's per capita fixed assets are much lower than SOEs and foreign-invested firms (Table 6).

4.2.3 Increase Production and Business Results of the Individual Economy of Vinh Phuc Province 
Table 7. Profit before tax of the private sector in Vinh Phuc province, 2010-2018 Unit: million VND

\begin{tabular}{lccccc}
\hline Profit before tax & $\mathbf{2 0 1 0}$ & $\mathbf{2 0 1 5}$ & $\mathbf{2 0 1 6}$ & $\mathbf{2 0 1 7}$ & $\mathbf{2 0 1 8}$ \\
\hline Total & 841,816 & 371,652 & 804,105 & 778,958 & $-9,706$ \\
Private & 40,511 & 2,528 & $-5,281$ & $-23,878$ & $-14,106$ \\
Limited liability company & 216,472 & 366,225 & 531,072 & 137,610 & $-180,232$ \\
& $-6,104$ & -265 & 15,111 & -222 & $-10,630$ \\
$\begin{array}{l}\text { State-owned joint stock companies } \\
\text { Joint stock companies do not have state } \\
\text { capital }\end{array}$ & 590,937 & 3,164 & 263,203 & 665,448 & 195,262 \\
\hline
\end{tabular}

Source: Vinh Phuc Statistical Yearbook 2019.

Table 7 shows that the pre-tax profit of the private sector of Vinh Phuc in the 2010-2018 period dropped sharply, specifically: in 2010, the pre-tax profit of the private sector in Vinh Phuc was VND 841,816 million, in 2018 it was $-9,706$ million in copper. In 2018, private enterprises, limited liability companies, and joint stock companies with state capital all had negative pre-tax profits. Profit before tax dropped the most was limited liability company in $2018-180,232$ million dong. In the period 2010-2018, the private enterprises and joint stock companies with state capital did the most ineffective production and business activities, the joint stock companies with state capital, the profit before tax in 2010 was $-6,104$ million VND and in $2018-10,630$ million VND. The subjective reason is that most of Vinh Phuc's individual economy is micro, small and medium enterprises. Effective quality of using labor in the private sector of Vinh Phuc is still low. In addition, corporate governance capacity is still limited, not participating deeply in national and global supply chains. On the other hand, it is due to the impact of the US-China trade war. When the US-China trade war broke out, the VND / CNY exchange rate continuously decreased and the decline level has been stronger since the end of June 2018. Thus, compared with the yuan, the VND is gradually increasing, making the price of Chinese goods in Vietnam cheaper, and the competitiveness of Chinese goods is increasing. That makes it difficult for Vinh Phuc's individual economic products to compete in the market.

4.2.4 Improving the Lives of Workers 
Table 8. Total income of workers in the private sector of Vinh Phuc province Unit: million VND

\begin{tabular}{|c|c|c|c|c|c|}
\hline Year & 2010 & 2015 & 2016 & 2017 & 2018 \\
\hline Enterprise & $1,216,429$ & $3,261,730$ & $3,967,887$ & $5,310,949$ & $6,413,386$ \\
\hline Private & 84,995 & 128,225 & 134,658 & 134,938 & 123,069 \\
\hline Private Limited Co & 619,547 & $1,763,673$ & $2,102,535$ & $2,964,214$ & $3,874,051$ \\
\hline $\begin{array}{l}\text { State-owned joint stock } \\
\text { companies }\end{array}$ & 28,642 & 33,752 & 31,899 & 28,027 & 40,598 \\
\hline $\begin{array}{l}\text { Joint stock companies do not } \\
\text { have state capital }\end{array}$ & 483,245 & $1,336,080$ & $1,698,795$ & $2,183,770$ & $2,375,668$ \\
\hline
\end{tabular}

Source: Vinh Phuc Statistical Yearbook 2019.

The income of employees in a limited liability company is the highest: in 2010 it was 619,547 million VND, in 2018 it was 3,874,051 million VND, increasing $625.3 \%$ compared to 2010. Income of employees at the company Joint stock companies without state capital ranked second: in 2010 was 483,245 million VND, in 2018 it was 2,375,668 million VND, increasing $491.6 \%$ compared to 2010 . Income of employees in private enterprises ranked 3rd: in 2010 it was 84,995 million VND, in 2018 it was 123,069 million VND, increasing 144.8\% compared to 2010 . Income of employees in joint stock company with state capital ranked 4th: in 2010 was 28,642 million VND, in 2018 it was 40,598 million dong, up $141.74 \%$ compared to 2010 (Table 8).

4.2.5 Contribution of the Individual Economy Vinh Phuc Province to the Local Economic Growth

Table 9. Contribution of the private sector of Vinh Phuc province in the value of GRDP Unit: billion

\begin{tabular}{lccccc}
\hline & $\mathbf{2 0 1 0}$ & $\mathbf{2 0 1 6}$ & $\mathbf{2 0 1 7}$ & $\mathbf{2 0 1 8}$ & $\mathbf{2 0 1 9}$ \\
\hline TOTAL & 42,686 & 86,267 & 95,334 & 107,625 & 118,958 \\
Private & 3,593 & 8,626 & 11,146 & 13,408 & 15,179 \\
\hline
\end{tabular}

Source: Vinh Phuc Statistical Yearbook 2019. 
In the period 2010-2019, the average annual growth rate of value added by the private sector to contribute to the province's economy is $11.07 \%$ / year. However, the scale of the added value created annually of this business is still low, reaching VND 3,593 billion (in 2010), by 2019, it will reach VND 15,179 billion. It shows that the private sector enterprises have not had a breakthrough in production technology, there are no businesses in this sector capable of creating added value that make a great contribution to the economy; Although the sector has great growth potential, coming from 4,889 private enterprises, limited liability companies, companies with state capital and joint stock companies with no state capital (2018); This sector contributes $12.76 \%$ of the province's GRDP value in 2019 . The development of the private sector has a direct impact on economic growth and social security. The individual economy has developed throughout the province, actively contributing to the distribution of goods to ensure consumption needs for the local population (Table 9).

\subsection{A General Assessment of Individual Economic Development in Vinh Phuc Province, Vietnam}

\subsubsection{Results Achieved}

The individual economy in the province has made positive contributions to the implementation of the province's socio-economic development goals such as creating jobs for 73,362 employees of the province, especially workers in rural areas create favorable conditions to increase income for workers; contribute $12.76 \%$ of the province's GRDP value; contributing to economic restructuring, labor structure, creating a breakthrough in job creation, hunger eradication and poverty reduction, contributing to speeding up the process. shifting agricultural and rural labor to industrial, service, etc. (Vinh Phuc Statistical Yearbook 2019)

The private sector of Vinh Phuc plays an important role in the development of products, goods and services and distributing these products to markets in mountainous and rural areas to meet consumer needs and social security.

The individual economy of Vinh Phuc innovates the way of doing business in the countryside, contributes to the creation of a new business style, concentrated production, and introduces raw commodity products into the value chain, is an impossible ingredient. lack of new rural construction.

In addition, the individual economy of Vinh Phuc with features: medium, small and super small scale, compact and lightweight organization, does not require too much investment capital, easy to find and satisfy requirements. limited demand in specialized markets; Having a direct relationship with the market and consumers should react quickly to market fluctuations. Therefore, the individual economy is very dynamic and flexible with the fluctuations of market demand. At the same time, in the development process, it is very flexible to learn, develop and avoid great losses caused by the objective environment.

The development of the individual economy in Vinh Phuc creates conditions to improve the manners and sense of observance of the labor discipline working in non-state enterprises. Employees in non-state enterprises are trained with knowledge to improve their awareness, 
behavior and discipline suitable to the enterprise.

Qualified and skilled human resources are gradually being focused on by enterprises, a part of employees in non-state enterprises have adapted and mastered advanced and modern technology in some fields. field. Business owners and a part of managerial staff have a dynamic and sharp mindset in the business of the marketplace, in changing business lines and acting as the focal point of various types of transactions and services. business. With high dynamism, the individual economy is both a start-up learning environment for entrepreneurs and an environment to create connections and accumulate capital to form and develop large businesses.

\subsubsection{Some Limitations}

- The number of enterprises in Vinh Phuc's individual economy operating in the economy is still low; Contribution of the individual economy in some economic indicators of the province, such as: Contribution rate in GRDP, contribution rate in total social investment capital, proportion of contribution to budget revenue is low. not commensurate with the development potential of the province;

- Difficult to access credit for production and business: Enterprises of the province are mainly small and micro enterprises with low ability to accumulate capital. Capital investment is minimal, especially medium and long-term capital, capital sources of enterprises are mainly loans, but access to capital sources from credit institutions is facing difficulties, enterprises cannot meet loan conditions. capital, lack of collateral.

- Competitiveness of the private sector in Vinh Phuc is still low: The quality and efficiency of production and business of the individual economy are limited, labor productivity is low, product quality is not high, and can be built. brand name, not reaching far, not standing firmly on the market, the business product is not stable and long-term. Most of Vinh Phuc's individual economy mainly serves the local market, especially service businesses. The linkage between the province's individual economy and with large enterprises inside and outside the province is weak (not yet becoming a satellite for large enterprises).

- The level of technology is limited, the machinery and equipment system is mostly old, out of date, with little innovation in production technology, the quality and competitiveness of products are still limited, there is no investment. in depth in science, technology and advanced production equipment. The scientific and technological content in the production of industrial and agricultural products of enterprises is still limited, with a lot of loss and consumption of resources and energy.

- Management team of enterprises still have limited knowledge and experience in management, modern governance, and slow access to information and market. The majority of labors in the private sector are low-skilled and lack skilled skilled workers.

- Vinh Phuc's individual economy has difficulty participating, linking, cooperating with FDI enterprises, large enterprises to form and participate in link clusters, value chains in the supply of products in a number of industries and fields that belong to the province's strengths 
and development potentials: mechanical engineering, electronics, informatics, tourism, agriculture, etc. The individual economy has not taken advantage of the spillover effect. Big businesses to take advantage of their own growth opportunities.

- Legal services to support businesses in the province to meet the needs of businesses are limited. Business support programs such as accounting, auditing, consulting, tax agents, and customs have not met the requirements of businesses. The quality of the lawyer team is not high, lacking in both quantity and quality.

- Innovation and start-up activities are still limited; An innovative start-up ecosystem has not been formed; have not mobilized the participation of companies and large enterprises in association activities, contributing to promoting the development of innovative start-ups in the province;

- Enterprises of the province have not paid attention to product branding and market research, and still depend heavily on the local market;

\subsubsection{The Causes of the Limitations}

Objective reasons

- The large FDI enterprises when investing in the province often have links with FDI enterprises specializing in providing supporting industrial products. On the other hand, for domestic enterprises with low capital scale, low level of production technology (often without a research and innovation division), the production process has not met the standards required by supplier. Therefore, it is limited to participate in the supply chain of supporting industrial products for large enterprises.

- The individual economy lacks information when it comes to joining and building business links with large enterprises, such as: Information on industry standards and how to meet these standards; information about the quality of goods and the ability of potential suppliers to deliver on time; information about the types of goods and products that large enterprises are looking for, choosing suppliers; ... .

The individual economy of Vinh Phuc still faces many difficulties in accessing land: on the one hand, the clearance and land acquisition procedures are often time-consuming, affecting the business plan of enterprises; land price calculation methods, licensing procedures, planning information still cause many frustrations, hindering the speed of recovering and handing over clean land to investors; on the other hand, land rental rates, high business costs, etc. to reduce the competitiveness as well as limit access to land, production and business premises of the individual economy.

Manual labor also accounts for a large proportion in the labor structure of the individual economy. Most of the workers in the individual economic sector come from rural areas, so their style, labor discipline, and professional qualifications are still limited.

\section{Subjective reasons}

Firstly, the working environment and the remuneration regime of the individual economy is 
still limited and cannot be satisfied by large enterprises and FDI enterprises. Therefore, it is difficult to compete with large enterprises and FDI enterprises in recruiting highly qualified labor to meet the requirements.

Second, the individual economy lacks collateral; Business activities are of short-term nature, have no long-term business vision and strategy, so the business plan is ineffective and does not meet the Bank's requirements; Enterprises have a need to borrow capital but have weak financial capacity, and business plans are ineffective; Many businesses have not yet built up a business strategy and plan.

Third, businesses have not paid attention to technological innovation and product quality improvement; not actively approaching science and technology. Management, corporate governance, research capacity, creativity, spirit of exploration, development and technological innovation of enterprises are limited; Low technology, production techniques, lack of product quality competitiveness. The coordination, cooperation, support and protection of each other in the production and business activities between enterprises is not yet tight, and the lack of professionalism reduces competitiveness.

Fourth, some entrepreneurs still have a strong psychology of small and small production; linkage, large-scale business cooperation to participate in the value chain is not much. The proportion of enterprises participating in business associations is still low; business clubs, slow-growing entrepreneurs; Business associations and associations have not yet fully played their roles for their members.

\section{Recommended Solutions to Promote Individual Economic Development, Vinh Phuc Province, Vietnam}

\subsection{Creating a Favorable Investment and Business Environment for the Individual Economic Development of Vinh Phuc Province.}

Authorities in Vinh Phuc province need to review, amend, finalize, and propose competent authorities to amend and complete a set of procedures related to investment licenses, construction permits, land access, access to information, costs incurred to do the procedures. By doing that, the business environment will be significantly improved, businesses will find business opportunities and have confidence in the market, in the authorities of Vinh Phuc province.

Promote socialization, create conditions for the individual economy to participate in providing public services, participate in the process of international economic integration. Supporting the individual sector to access and exploit opportunities in international integration, expand markets, and promote international investment and trade. Create favorable conditions for the individual economy to develop and enhance the capacity to step by step deeply and firmly participate in the regional and global value chains.

Promote the development and implementation of e-government and internet data sharing to improve the transparency and quality of public services, give priority to the implementation and integration of public procurement and electronic bidding; Strengthen public private 
dialogue mechanism between small and medium enterprises and the Provincial Government.

5.2 Support to Develop Feasible Production and Business Plans to Improve Access to Credit for the Individual Economy in Vinh Phuc

Train, advise, guide and provide information for the private sector to develop feasible business plans, strengthen management capacity, management skills, and transparent financial information. requirements of banks, improving access to credit from: Vinh Phuc Province Credit Guarantee and Investment Fund; transaction offices of banks in Vinh Phuc province: Joint Stock Commercial Bank for Investment and Development of Vietnam, branch of Vinh Phuc, Joint Stock Commercial Bank for Industry and Trade of Vietnam, branch of Vinh Phuc, Bank Agriculture and Rural Development Vietnam branch Vinh Phuc;

\subsection{Supporting the Individual Economy Vinh Phuc Strengthens Its Financial Capacity,} Innovates, Modernizes Technology and Develops Human Resources, and Improves Labor Productivity

Encourage and support the individual economy with specific policies, invest in research and development activities, and transfer advanced technology. Ensuring effective enforcement of the law on intellectual property. Development of funds to support innovation and technology application. Apply tax policy, financial support, access to preferential capital sources suitable to technology research, innovation and modernization.

Improve the quality of education and training, especially vocational training, train high-quality human resources to meet the demand for quantity and quality of human resources for individual economic development. Strengthening cooperation and close linkage between enterprises and training institutions. Development of training according to the needs of businesses and the market. Focusing on training, fostering and developing a team of businessmen with high professional qualifications, modern management skills, business ethics and high sense of responsibility.

\subsection{Strengthen the Inspection of the Implementation of State Mechanisms and Policies} Towards Organizations and Individuals in Order to Improve State Management Efficiency

Along with the development and improvement of the legal framework, it is necessary to create more favorable and equal conditions for the individual economy; It is necessary to improve the capacity to build and organize the effective implementation of laws and policies, creating a favorable and safe business and investment environment for the healthy and right-oriented individual economic development.

Enhance effectiveness of supervision, inspection and accountability of all levels for the observance of the Party's undertakings, State policies and laws on individual economic development. Strictly handle acts of violating the law, so as not to affect the production and business activities of enterprises.

\subsection{Resolutely Implement the Simplification, Publicization and Transparency of} Administrative Procedures in the Administrative Reform Program of Vinh Phuc Province 
Strictly regulate and supervise the simplification, shorten the time to process administrative procedures for enterprise establishment, business registration, licensing, taxation, dispute settlement,... Strengthening the dialogue mechanism effective between state management agencies and enterprises in the individual economic sector in Vinh Phuc to grasp and promptly handle problems related to individual economic development.

There is a need to pay more attention to reforming and simplifying business establishment procedures and logistics costs. Make public and transparent unofficial fees, promote the application of information technology, reform administrative procedures, and facilitate inspection and accountability of the heads and assigned agencies. for the establishment and development of the individual economy in Vinh Phuc.

Research to reduce and appropriately adjust the cost of accessing public services such as business registration, trademark registration, and customs tax declaration to create favorable conditions for business operations of the above enterprises. in Vinh Phuc province.

\section{Conclusion}

With overall solutions to create a favorable investment and business environment for individual economic development; Support to develop feasible production and business plans to improve credit accessibility; Supporting the private sector to strengthen financial capacity, innovate, modernize technology and develop human resources, improve labor productivity will contribute to promoting economic development local authorities as well as effectively manage activities of the individual economic sector in Vinh Phuc province in the process of international economic integration.

\section{References}

Bui, V. (2010). Characteristics of the private economy in the current socialist-oriented market economy in Vietnam. Journal of Transport Science, 32(Vn.).

Central Institute for Economic Management (2018). Topic No.18: Development of the private economy and economic restricting in the conditions of technology revolution 4.0. Information - Data Center, Hanoi (Vn.).

Cunningham, W. \& Alidadi, F. (2014). Vietnam's employment future: The role of the private sector. Australian strategic partnership - World Bank Group in Vietnam (Vn.).

Doan, T. (2012). Commercial sector of the private sector in Vinh Phuc - Current situation and solutions. Journal of Science and Technology, 88(12), 85-91.

Information and electronic communication in Vinh Phuc province (2009), "Evaluation of private economic development in Vinh Phuc". Retrieved from https://www.vinhphuc.gov.vn/ct/cms/tintuc/Lists/ThoiSuChinhTri/View_Detail.aspx?ItemID $=2996$

Le, D. (2020). Vinh Phuc: Looking back on the socio-economic development after 5 years (2015-2020).

Retrieved from https://dangcongsan.vn/vinh-phuc-tiem-nang-va-trien-vong/vinh-phuc-con-nguoi-va-truyen-t 
hong/vinh-phuc-nhin-lai-chang-duong-phat-trien-kinh-te-xa-hoi-sau-5-nam-2015-2020-5619 94.html

Le, H. (2013), Historical master thesis "Party Committee of Vinh Yen city, Vinh Phuc province with private economic sector 2001-2010". Hanoi National University, University of Social Sciences and Humanities (Vn.).

Nguyen, S. (2017). Affirming the position and role of the private economy in the Vietnamese economy. Retrieved from https://tapchitaichinh.vn/nghien-cuu-trao-doi/khang-dinh-vi-tri-vai-tro-cua-kinh-te-tu-nhan-tr ong-nen-kinh-te-viet-nam-127594.html

Pavone, L. (2015). How the private sector can advance development. Retrieved from https://www.oecd.org/development/development-posts-private-sector.htm

Pham, B. (2018). Private economy: An important driving force in Vietnam's economic development. Retrieved

from https://tapchitaichinh.vn/nghien-cuu--trao-doi/trao-doi-binh-luan/kinh-te-tu-nhan-dong-luc-q uan-trong-trong-phat-trien-kinh-te-viet-nam-134456.html

Pham, D. (2018). Private economic development in Vietnam under the impact of improved legal environment. Retrieved from http://tuyengiao.vn/nghien-cuu/ly-luan/phat-trien-kinh-te-tu-nhan-o-viet-nam-duoi-tac-dongcua-viec-cai-thien-moi-truong-phap-ly-113810

Phan, H. (2019). Private agriculture in Hai Duong province. PhD thesis, Ho Chi Minh National Academy of Politics (Vn.).

Truong, D. (2017). Developing the private economy in the socialist-oriented market economy in Vietnam. Retrieved from http://mattran.org.vn/hoi-dong-tu-van/phat-trien-kinh-te-tu-nhan-trong-nen-kinh-te-thi-truong -dinh-huong-xa-hoi-chu-nghia-o-viet-nam-9296.html

UNESCO (2016). Empowering the private sector to drive economic growth in low-income countries.

from http://www.unesco.org/new/en/media-services/single-view/news/empowering_the_private_se ctor_to_drive_economic_growth_in_lo/

Venables (2015). The role of the private sector. Retrieved from https:/gsdrc.org/topic-guides/urban-governance/elements-of-effective-urban-governance/therole-of-the-private-sector/\#: :text $=$ The $\% 20$ private $\% 20$ sector $\% 20$ provides $\% 20$ around,the $\% 2$ 0efficient $\% 20$ flow $\% 20$ of $\% 20$ capital.

Vinh Phuc Statistical Office (2020). Vinh Phuc Statistical Yearbook 2019 (Vn.). Statistical publisher (Vn.).

Vinh Phuc Provincial People's Committee (2019). Project on Support and Development of Small and Medium Enterprises in Vinh Phuc Province in the period 2020-2025, Draft 1 (Vn.). 


\section{Macrothink}

Journal of Asian Development

ISSN 2377-9594 2021, Vol. 7, No. 1

$\mathrm{Vu}$, A. (2019). Private sector in the Vietnamese market economy. Retrieved from http://tapchinganhang.gov.vn/khu-vuc-kinh-te-tu-nhan-trong-nen-kinh-te-thi-truong-viet-nam .htm

Vu, P. (2019). Private economy: Concepts and solutions for development. Retrieved from https://hcma.vn/tintuc/Pages/tin-tuc-su-kien.aspx?ItemId=29919\&CateID=0

Wigmore, I. (2013). private sector. Retrieved from https://whatis.techtarget.com/definition/private-sector

Xuan, H. (2017). Basic solutions for private economic development. Retrieved from https://dangcongsan.vn/kinh-te/nhung-giai-phap-co-ban-de-phat-trien-kinh-te-tu-nhan-44408 $0 . h t m l$

\section{Copyright Disclaimer}

Copyright for this article is retained by the author(s), with first publication rights granted to the journal.

This is an open-access article distributed under the terms and conditions of the Creative Commons Attribution license (http://creativecommons.org/licenses/by/4.0/). 